\title{
Control relation change into trust relationship in volunteering
}

\author{
Vida Gudzinskiene and Neringa Kurapkaitiene \\ Mykolas Romeris University, Vilnius, Lithuania
}

\begin{abstract}
The phenomenon of volunteering reveals itself through the time a person spends for volunteering, through the duration of the volunteering, the area in which volunteering occurs, and the age group of the volunteers. Object of the study - volunteering experiences of young adults. The issue of the research is how young adults experience volunteering in the social help field. The research is phenomenological and not focusing on any foreseen objectives, oriented to the experience of the volunteers. According to phenomenological approach, research methodology was Interpretative Phenomenological Analysis. In this article, part of the research is presented, giving deeper view on one of the super-ordinates theme, with the aim: to present change of control relation into the trust relationship with the Other in long term and full-time volunteering. In the study participated 6 research participants, 3 young men and 3 young women, 20 to 30 years old. To collect data of the research we used semi-structured interviews. Conclusions of the study, presented in this article, reveal: 1) The volunteers' experience of volunteering shows that the relationship of control in trying to fit the lives of met people into a personal imagination - what life should be like changes through confrontation, surprise and even shock to discover authentic relationship of trust based no longer on appreciation but on intimacy and communion; 2) Hidden abilities of volunteers, new opportunities and self-disclosure are possible when a close relationship of trust is created; 3) Abandoning preconceptions about the Other and volunteering, the study participants changed the relationship of control to a relationship of trust. On that base, they began to volunteer in their environment without waiting for permission, instructions or other actions to legalize volunteering. As the relationship changed, as control shifted to a trust-based relationship with those around them, volunteers, realizing the experience, discovered the significance of volunteering, empowered by trust, and personal freedom and creativity; 4) The relativity of the study participants in volunteering was experienced dialogically, seeing the person and associating themselves with the person, and thus experiencing a constant interplay as ignorance, uncertainty, but at the same time as devotion and trust.
\end{abstract}

Key words: volunteering, interpretative phenomenological analysis, control relation, trustful relationship.

\section{Introduction}

Volunteering is a free will activity, not financially remunerated, the benefits of which are provided to the society and community, not to relatives, or other persons closely related to the volunteer. Volunteering is implemented in formal and informal way. Informal way is when volunteering takes place without any official organisation, but formal way is when volunteering is organised in non-profit organizations. Regardless of their socio-economic status, education, cultural background, age or gender, every individual has the right of voice 
and the right to contribute to their community [1]. Volunteering in Lithuania and generally in the World is recognized as diverse and dynamic phenomenon, revealing itself in different forms, depending on time, volunteers' characteristics and area, where volunteering takes place. According to the duration [2,3], volunteering can be divided into different forms of volunteering - short term or long term, or other. According to the time given for volunteering [4], it can be divided into episodic, part - time or full - time and other; as to the volunteering area $[5,6]$, it can be divided into - social help, environmental, cultural, health supporting and other; according to the age of volunteers $[7,8]$ - into young adults, seniors and others. In the $20^{\text {th }}$ century, the number of researches in volunteering increased. Researchers tried to understand the phenomenon through diverse characteristics - interaction of volunteering with organisations [9-13], the benefit of volunteering for the volunteers [1, 14] the impact of volunteering to the labour market $[15,16]$, volunteering as the possibility for inclusion in volunteering [17], volunteering as learning opportunities [1, 6, 18-21]. It should be noted that the researches are implemented without defining all the characteristics of a particular volunteering, but volunteering processes and their expression can differ quite strongly between volunteering experiences with different characteristics of volunteering. Paradigm of learning in volunteering is also open, but how volunteers experience learning as learners is not researched. Here the issue is emerging - how volunteers experience volunteering as a learning experience.

The object of the study - Experiences of young adults volunteering.

The question of the research - how do young adults experience volunteering in the social help field? In this article, one aspect of the research is represented - the change of control relation into trust relationship during a long-term and full-time volunteering.

The aim of the research - to reveal the change of the control relation into trustful relationship with the Other in volunteering of the young adults.

Objectives:

1. To represent the process of the control relation change into trustful relationship with the Other through long - term and full - time volunteering experience of the young adults.

2. To discuss change of relation of volunteers with learning and ethical philosophy theories as the background of changing existence with the Other.

\section{Methodology and research participants}

In order to carry out a phenomenological study, we have focused on intensive and continuous methodological approach, retrospective self-reflection, in terms of personal volunteering experience, and reflection on the research conducted. Research design based on Interpretative Phenomenological Analysis (IPA), where the main purpose of IPA is not only to reveal unique meaning in life of the participant (phenomenological part), but also to the content and multilayer (interpretative part) that is not always visible [22]. IPA is an ideological posture based on a certain phenomenon in a particular context. What is more, IPA is conducted with a small group of study participants. "The lever of subjective interpretation is the analysis of the author's idea. It ensures the unity of the whole study: in every study there is an "inner core" where all thoughts of the author evolve" (Schleiermacher, QTE by Smith at al., 2009). The role of the IPA researcher is to understand how the participants of the research are trying to perceive their experience. Steps of Interpretative Phenomenological Analysis are Multiple reading - Phenomenological comments - Interpretative comments - Topics Clusters (of a participant) - Topic clusters (of several participants) - Meta-themes. It is important to note that the IPA study is primarily a creative research and reliability should 
Table 1. Age of research participants during volunteering and during participation in the interview.

\begin{tabular}{|l|c|c|c|c|}
\hline $\begin{array}{l}\text { Research } \\
\text { participant }\end{array}$ & $\begin{array}{c}\text { Age at the } \\
\text { beginning of the } \\
\text { volunteering }\end{array}$ & $\begin{array}{c}\text { Age at the end of } \\
\text { the volunteering }\end{array}$ & $\begin{array}{c}\text { Duration of the } \\
\text { volunteering }\end{array}$ & $\begin{array}{c}\text { Age during the } \\
\text { participation in } \\
\text { the research }\end{array}$ \\
\hline 1 woman & 22 years & 23 years & 12 months & 25 years \\
\hline 1 woman & 22 years & 23 years & 12 months & 26 years \\
\hline 1 woman & 25 years & 25 years & 6 months & 27 years \\
\hline 1 man & 19 years & 20 years & 9 months & 21 years \\
\hline 1 man & 25 years & 25 years & 6 months & 26 years \\
\hline 1 man & 23 years & 24 years & 16 months & 29 years \\
\hline
\end{tabular}

not limit the creativity of the researcher, but the opposite, should be broad enough to allow the researcher to accomplish a creative and systematic study and to provide data [22, 23]. The IPA primarily focuses on the phenomenological experience of the research participants. It seeks to understand the perception of the experience by analysing and naming frustrating topics, clusters, topic clusters and meta-themes. Only after the analysis of the participants' experience through volunteering in the discussion part is made, another step of interpreting the analysis of the participants' experience through learning perspective can be taken.

Considering the saturation of the study and J.A. Smith's (2007) recommendation to limit the study to a small number of study participants, in the research participated 6 ex-volunteers -3 young women and young 3 men aged 20-30 years. Selection of the research participants by IPA methodology is recommended to ensure the homogeneity and diversity of the research participants. Homogeneity of the research participants was ensured with age frame - all research participants participated in the voluntary activity when they were young adults (18-30 years old) and participated in the study interview while they were still in the same age group. Homogeneity is ensured also by the area of volunteering - social help area and time given for volunteering - long-term and full-time volunteering. The research participants were volunteering not less than 20 hours a week and during volunteering period they had no additional activities, such as study or work, it means volunteering was their main activity for this particular time. Duration of volunteering was not less than 6 months. All these criteria ensure that research participants had enough similar experience, which is suitable for the interpretation and analyses in the IPA research. In highlighting the diversity aspects of the research participants, it should be noted that ex-volunteers are not concentrated in one living or volunteering area, they are of different genders, different ages, different volunteering countries and different organizations. It ensures that the integrity of their experiences is only defined by the experience of volunteering, which is homogeneous according to the requirements of the research. The age of the research participants during volunteering and during the research is represented in the Table 1 below:

According to the IPA methodology $[22,23]$ participation in the research is completely voluntary, all the participants were invited through organizations, responsible for coordinating volunteers, and voluntary service programs. The volunteering process of the research participants has been experienced in the past, i.e. retrospective experience gained through European Voluntary Service program (4 study participants), through the Voluntary Service for Young People: action programme (1 study participant) and through the International Voluntary Service Programme created by the Point Coeur Organization (1 study participant). As projected, the minimum duration is 6 months, with a maximum duration of 16 months. All the participants of the research volunteered in the area of social assistance, and their 
Table 2. Duration and dedicated hour per week for volunteering of the research participants.

\begin{tabular}{|l|c|c|c|}
\hline $\begin{array}{l}\text { Research } \\
\text { participant }\end{array}$ & $\begin{array}{c}\text { Voluntary Service } \\
\text { Programme }\end{array}$ & $\begin{array}{c}\text { Dedicated hours per } \\
\text { week for volunteering }\end{array}$ & $\begin{array}{c}\text { Duration of } \\
\text { volunteering }\end{array}$ \\
\hline 1 woman & European Voluntary Service & 30 & 12 months \\
\hline 1 woman & European Voluntary Service & 30 & 12 months \\
\hline 1 woman & Youth Voluntary Service & 20 & 6 months \\
\hline 1 man & European Voluntary Service & 30 & 9 months \\
\hline 1 man & European Voluntary Service & 30 & 6 months \\
\hline 1 man & Point Coeur & 40 & 14 months \\
\hline
\end{tabular}

experience based on communication and social assistance for the recipients. The duration of the volunteering and dedicated hours per week for volunteering we represent in the Table 2 below:

The study adopts in-depth, semi-structured interviews, based on the recommendations of Smith (2009) - questions are open ended and broad, so that the participants could share their views and individual experiences without any limitations. During the interview, the questions about learning were not raised. Any direct questions about learning - could prevent an authentic participant's view on volunteering experience and project an unconscious attempt to meet the imaginary or heard requirement - what should have been learnt; this leads to replicate and "template" outcomes of learning. Smith (2009) enables the researcher to look for indirect questions, related to the research issue, and to discover questions that lead to revealing deep and authentic experiences [22]. Volunteering requires entering new environment, meeting new people and engaging in new activities, all of that becomes a way of inevitably spontaneous learning for young adults. It leads to a presumption, that any experience through volunteering could be recognized in phenomenological way as a learning experience.

Transcription of the research interviews and narrative of the research participants is quoted with these signs:

[] - part of quotation is removed seeking to reveal main thought of the research participant;

$(\ldots)$ - with multipoint in quotation we mark pauses, up to 7 seconds and indicated in square brackets;

(silence) - is remarked, when pause is longer, than 7 seconds;

( ) - in brackets, we describe notes connected to the behaviour of the research participant;

(Saule, 123) - at the end of the quotation we write the name (changed) of the research participant and the number of the line in the interview;

bold - strong and laud pronounced word or phrase during interview.

The quotes of the research participants are written in italic.

\section{The results of research and analysis}

After the analysis of the material of the in-depth interview, one of the important findings is the experience of the control relationship between volunteering and the relationship of trust with another in long-term and full-time volunteering. The participants of the research volunteered 
to get away from the usual environment, normal relationships, and people they were used to. When confronted with other people, the volunteers first of all experienced themselves as different: [to get to know people you would not normally meet in life, there punks are all [...] you're already different when you go there because you're not, not, not dark skinned, you don't speak Spanish (Karolina, 520, 523). After repeating 'not' several times, Karolina stressed that she is very different from the people she meets, who do not have an external explanation (skin, colour, language) and many things which remain inexpressible in words, are experienced internally, emotionally and almost secretly. Being different and the otherness of the other frighten me with my unusualness and fear that by accepting the others I will become like them: At first, I was very scared (sighed) of those people. Their looks, their ... saliva everything. Well I don't know, just. Such first impression (sighs) and I understand when they changed, they became friends, (...) there are Aurimas, Andrius, there are a few more (deeply breathes in) (Eimantas, 54-55).

The fear disappears when the volunteer descends into a personal relationship, transcends the inadmissibility, boundary of the external image, and opens up in person. Through proximity to other volunteers, the participants of the research become different, which reduces the requirement for what kind of people should be around. Perceiving yourself as a stranger widens the boundaries of tolerance, forgiveness, and not being demanding: [I would say that our view of the world expands much more because you are more tolerant to others [...] the differences begin to appear in the positive way, in the sense that you find that differences are good (Karolina 522, 524-525); It's maybe like that, I tell me it's not even that I learned a lot there not to do it with people anymore, but from the understanding that very often, that's the stamp he's so and so, the stamp is the stamp. It was such a good experience with Roben... too... (Eimantas, 767-769). Faced with the Other, change my thinking, attitudes, look at the other with different eyes: [I realized that (sighs) very often I somehow put people in some kind of frame, in the sense that I appreciate, underestimate, well somehow like this. He is such, he is different and (sighs) (Eimantas, 4747-749). The discovery of yourself as a different one, arises from an unequal relationship with another person, where the underestimation of the other without deepening over time reveals a distorted view of man in clichéd thinking: after that, I understood that before I came, his daughter was raped and he knew who did it. The third, in the end, at the very end of the mission, his other son Alan, killed a person during one robbery (...) on the other hand, leaving volunteering, while I was so calm of him (Eimantas, 753-757). While sharing the thoughts of his stereotypical thinking, Eimantas acts as giving a confession, addressing me, the researcher, verbally, as if seeking approval and forgiveness for himself for condemning the other or forcing him into a judgmental evaluation.

The participants of the research re-evaluated their thinking about the other, using experience - people did not fit into the pre-arranged frames in any way: And how else do I think? [... ] I have completely changed it, you know, a different attitude (Eimantas, 759, 761). When I say I have completely changed it, Eimantas expresses not only the changed attitude, but also the relationship with the one he helped to change - the evaluative relationship moved to authentic, seeing the new person with his inner gaze. Eimantas seems no longer demand how the other person should be, and instead of demanding, the enemy sees himself differently with his life experience that opens up to a relationship.

The participants of the research, who first started volunteering, experienced tension, considering whether their volunteering made sense, and in an effort to get rid of the anxiety caused by anxiety, tried to do what was normal for them, using the idea of what volunteering should be: [absolutely so stressful and I thought God like how I'll manage all this, how I will change the diapers, and if I'm wrong I put it on, and he said something to me in 
Spanish and I didn't understand anything. From the beginning there was, there was such (breathes), there was such a nerve (Karolina, 147-150); I really got all my order there somehow, I don't know, accustomed to, well probably, in general here's a character trait so there my somehow want to do. [...] It was strange to me at first that we prayed so much in that chapel somewhere and did nothing. [...] I thought that volunteering was my thing - let's come and do it. Let's - do it! Well, you have a result, to achieve a goal somehow, or such (Eimantas, 249-251; 267-269). Eimantas was especially upset that he could not implement his plan - to act. He felt constrained not to do any of the activities for which he came to volunteer. Kęstas was frustrated by the lack of activity, not being able to take on the tasks he imagined he would have to do: as Lithuanians, we are used to work, work and work (95-96). By identifying with the role of teacher, he used previous experience to set a task and implement it without waiting for tasks from the organization: I had attended folk dances and I decided to teach those young people to dance (Kęstas, 100-101). By associating volunteering with dancing from the past, Kęstas seems to be revealing his potential by gaining new experience. Over time, the participants in the research began to become cramped realizing that their presence was insufficient because they themselves narrowed the meaning of being a volunteer. In order to control and squeeze themselves into imaginary frames, the volunteers seemed to wander aimlessly and sought to fulfil their own expectations as they would like to see volunteering. After changing the direction from imaginary volunteering to people nearby, the perception and behaviour of the research participants began to change: $I t$ was necessary for that volunteer to (laugh) learn to be somehow with others, well (...) go down, maybe somehow understand why others want something (Eimantas, 249-53); I thought about how to help her, well very often I not only thought about how to help, but I looked and felt like her. There I felt all sorts of feelings for her as well. It seems that I took over the feelings from her somehow (Saulè, 105-106). By abandoning preconceived notions of volunteering, study participants began to develop volunteering in their environment without waiting for instructions, permission, or other actions to legalize volunteering. The opening up of situations was based on putting the relationship here and now in the first place and "pulling aside" the relationship without the relationship: Somehow one person had an epileptic seizure there and I got there was to him and I could help him there and he recovered. I thought so too, so well like, somehow, I understood that as some kind of sign (breaths deeply) (Eimantas, 292-295); I watched what was going on there. [...] I started such handicrafts there, but to organize such oral ones (for girls - author's note) [...] (...)I don't know (Saule, 150; 152-154); Interesting was the script that we needed to write it [...], we created ourselves as what kind of things to say. This is how I felt as a mini-screenwriter (Kęstas, 127-128).

As the relationship with those around them changed, study participants felt free and creative in volunteering, began to do what they saw would fit, and developed a sense of their own, empowered by trust. In volunteering, the relationships of the study participants were developed and lived with very different people and very differently in each case. Intensive relationships with clients (locals) were developed and experienced by Eimantas: [volunteers found very suitable areas for some people. With some I get it somehow, with others I don't, and we were very divided, we could communicate there with very different people. It was one of those I thought it was all these criminals so local, they shoot there to look (inspire) and it was very interesting with them (316-320). Saule: it was, that I would say, one particular girl - what will I do when you leave, well, that I, she said, I have little idea how she will have to be here, yes. Another was a child who always trusted me there, rejoiced there somehow (...) (113-115). Ieva: I say, a part of myself, my culture, told me where I came from, they would never go there and they really feel that it is interesting to them (183-184). Relationships of similar intensity have been established and experienced by Karolina and Kęstas, but not with clients, but with other volunteers: for example, my closest friends here are volunteers and 
we agree best with volunteers because they are so open. Not so much that they are people volunteers, but only those because they have adapted well to the local culture and they are so completely (Karolina, 294-296). Emphasizing the uniqueness of volunteers, distinguishing them from other people, Karolina names the importance of a relationship with volunteers. Kęstas and other volunteers got involved in various projects and implemented ideas together, supporting each other: we are both new with that German, we don't know how that system works, how everything is there, we saw it (Kęstas, 181-182); [.. ] we organized, I just started organizing photos and we were interested in raising funds in the sense, photos there made in very high resolution, such portraits of those people [...]. Surely, I could say here that a lot of initiatives have been taken (... ) many sectors have been tested (Kęstas, 275-276; 283). Viktoras, like other volunteers, attached great importance to the relationship: [...] I wanted more activity, more projects and somehow hoped for more relationships with people, a relationship such that (...) [...] people are available all the time and everything happens there, social life is boiling, just somebody is playing, somebody is dancing, what is there, whether there are activities or not, just people come and do (52-54). However, he failed to create a relationship between staff, clients, or volunteers that he would enjoy, meaningful: And in Portugal, the centre was more (...) (sighing) so formal, people didn't come to do anything (...) anyway. That was a little sad. What struck me most was that I didn't have as much activity as I thought I would have and so much contact with people. And the people, who usually came, were the same in their continuation, already became friends and the same circle was spinning and spinning, there were not many new people (Viktoras, 55; 57-58). Unable to build a close, trusting relationship, Viktoras was disappointed not only with volunteering, where he felt alone, but also with activities that no longer made sense. Viktoras tried to come up with an activity for himself because it was not enough at the centre. However, control is suppressed, as is the case with other volunteers, and Viktoras did not build the relationships he could rely on to engage in creative activities, and his volunteering, when the activities were not based on relationships, lost its meaning.

The importance of the relationship in the perspective of volunteering has revealed itself by being irreplaceable and exclusive. Volunteering begins to change and integrate into the needs of the organization and/or community when there is a close relationship with a group - staff, beneficiaries and/or residents. For volunteers themselves, an activity makes sense when its foundation is close, when the relationship with one, several or a group of volunteers and the people working together is based on trust. The control relationship of the research participants, in an attempt to fit the lives of met people into a personal imagination of what life should be like, changes through encounter, surprise, and even shock, discovering an authentic relationship of trust based no longer on appreciation but on intimacy and communion. The experience of the research participants shows that hidden abilities, new opportunities, self-disclosure are possible when a close relationship of trust is created.

\section{Discussion: linking the research participants' experiences with relevant theories in search of answers to the research question}

When considering how the research data can relate to the prevailing theories and research, it was important not to leave behind the experiences of the research participants, but to bring them together with the theories and research into an equal relationship. Theories and research were accumulated during the research period until the end of the research analysis without analyzing them, but postponing interest in them until the research analysis was completed. After the analysis of the research data, the literature corresponding to the research data was 
searched, which would at least partially discuss the results of the research. By linking them to relevant theories, answers to the research question raised were sought.

Relationships with other study participants survive as an essential experience of being and becoming a volunteer. Relationships with others gave rise to a desire to volunteer, relationships with others led to the prospect of being a volunteer, and self-perceptions of volunteering emerged. Relationships with other volunteers in the research are experienced in two ways: experience of a relationship of trust and experience of a relationship of control. This article discusses the change in the relationship of control from volunteering to a relationship of trust with another. It should be noted that in the case of a control relationship with the Other, the experience of volunteering is framed by distrust of those responsible for volunteering.

The relationship of trust emerged in the research as a red thread that made study participants volunteers. Lacking a trust relationship or not experiencing it at all, study participants had difficult experiences and, although they volunteered, they did not feel like volunteering and did not survive volunteering. Volunteering remained as if behind glass and, separated from the people around it, endured the time devoted to volunteering by "doing something". The participants were surprised that the relationship of trust, which grew into friendship, arose with people with whom they would not have even tried to build a relationship outside of volunteering - a British volunteer with autism was best friend (Karolina, 49-50); people with intellectual disabilities. At first, I was very scared of those people. Their looks, their ... saliva everything. [...] Such a primary sense, I understood it got changed, when they became friends, (...) there is Aurimas, there is Andrius, there are a few more (Eimantas, 54-55); a forty-year-old, impoverished woman, that friendship of ours [...] we became friends. It was really a wow, unreal, because (...) well I don't know, maybe there are people who can somehow be with people of different ages there. Well, we somehow made great friends with her (Eimantas, 348-353).

Self-awareness through a relationship of trust with the less able led to the acceptance of personal disabilities, weaknesses, and imperfections. In building a relationship of trust, study participants experienced a truer self-image - by trusting a person with a disability, a person living in poverty, a criminal, and/or an addicted person, they accepted themselves, their inner disabilities, and weaknesses. Elias (quoted by Kunkler) [24] identifies relativity as one of the key aspects that "everyone (germ. Einzelnen) can only understand from and through life with others." Everyone can understand what we see in front of us not through an individualistic and not through a collective understanding, but a dialogue between [25]. Dialogue between is the possibility of two people interacting. Every Other that we can understand "from and through life with others" can also be the one that I begin to understand anew by living with others with whom I have not lived before. The understanding of the self through a relationship with others hitherto disagreed with others is described as a critique of the substantive understanding of the person, because man is understood as constantly changing, relative. Relative means not just being open to a relationship or being able to be in a relationship. Relative, according to N. Elias (according to Kunkler, 2011) [24] is an ontological opposition of the substantive and defines the person as not a substance but a relative one.

The relationship of trust that the participants of the research associate with the relationship of recognition from authority opens up a perspective in which a person becomes a purposeful volunteer. I would like a little bit of that surface to rub against me (hand rubbing my shoulder) [...] that in some diffusion way I would take over a little of those qualities then I seem to have succeeded in that experience just because (Ieva, 255-259) and [...] those deaths there those questions somehow, [...] unbearable they are so little, it accompanied us, we had, it was very important to us [...] (Eimantas, 596-599). The participants of the research, having 
experienced trust through a relationship with those they look at with respect, began to feel a responsibility that stems only from the relationship and from nothing more. Liability arise neither from the abundance of tasks, nor from the lack of tasks. A sense of responsibility is not experienced because of the orderliness, beauty or clutter and disgust of the volunteering environment. Levinas [26] says that feeling, experiencing, and cultivating or educating responsibility is possible only by building a relationship with the Other who entrusts his share of responsibility to the new trustee [24, 27]. The relationship of recognition from authority and the relationship of trust from the research participant developed a relationship of inter subjectivity.

Kunkler [24] argues that "man is relative and relativity is not only part of a certain process, but man himself is a process" [24]. Everyone understands something only from living together and living together with others. Relational thinking (Denken-in-Relationen) is a contradiction or alternative to substantive thinking (Denken-in-Substanz), and thus relation is given an ontological preference. This means that the relationship is not considered as a retrospective relationship between already existing entities and instances, on the contrary, it is argued that these entities, in their special form, arose only during and from the previous relationship.

Relational thinking-based learning takes place in a relative between Kunkler [26], based on Buber [25]. The relationship between volunteering has been experienced through vague, unanswered life situations of those whom volunteers help and experiencing the fragmentation of help provided by the participants of the research: well I don't know now how I remember it somehow, well a lot of such painful things (Saule, 194); Hygiene, well, tragic in those at home, feces, everything there. Well just there, that's how they live (Eimantas, 308); they watch and they don't remember what to say, it's a trifle here, but they don't know which way they need to go and stand on both sides with four workers and show everyone there orally (Ieva, 233).

After the onslaught of helplessness, despair and the experience of inferiority led the study participants to a search for support that was not methods or tasks, but another person who could endure the volunteer's experience of severe helplessness without condemning the volunteer and requiring nothing from him. Recognition from a freely chosen authority for the participants in the study meant acknowledging their existence quite valuable, accepting their confusion, helplessness, and fragmentation of the assistance provided. Recognition discourse or recognition as an indicator of relativity in different aspects has been explored by Honneth [28], Butler [29] and Kunkler [24]. Honneth [28] presents recognition in three essential forms of expression in human life. The first is recognition as care or love when the welfare of the Other is taken care of, and it manifests itself in an asymmetrical relationship of care and care to the Other, which can be recognized between parents and children or also through friendship. Such recognition serves the formation or restoration of self-worth when the Other grants recognition to the person as unconditionally valuable. This form of recognition is particularly necessary in the context of physical exploitation as a basis for self-confidence. The second form of recognition is moral respect, where there is deception and deception that destroy self-esteem. Self-esteem is restored only when at least one person appears who expresses moral respect. The third form of recognition is solidarity or loyalty with a person who is humiliated or disrespected. A person who experiences humiliation and disrespect loses self-esteem and self-esteem is restored when the Other recognizes the person and draws him from the individual into communion.

The concept of Honneth recognition is broadly expressed as "individuals or groups as an affirmation of good human qualities" [28], which partly describes the recognition experienced by study participants when they experienced helplessness, authority loyalty, and opened up for further volunteering experiences. Butler [29] similar to Honneth [28], interprets the 
phenomenon of recognition through "negative phenomenology". The need for recognition is not distinguished through moral insult or injury, but through the phenomenon of personal loss. In the perspective of loss, Butler raises the question of who I am without you. This confirms that we not only have a relationship, but in, a sense, we are in a relationship. The relationship is not outside of us, we exist in it. "Applying for or giving recognition does not mean claiming recognition when it is being prepared for it. It means asking your being once again, initiating change (Verwandlung in German), where the future is asked to stay always in a relationship with the Other" [29]. Recognition also plays a role in change for the recognized, as the recognized entity "in every process of recognition, when I become Other than I was before, through which I lose myself, I return to the question of who I am. There is a permanent loss in the recognition process, where the "I" in the act of recognition is constantly transformed, only its past is incompletely presented and accepted in this act. The act of recognition transforms the structure of each past (Organization) and its meaning, and at the same time transforms the present of the one who is experiencing recognition" [29]. In the experience of the study participants, the recognition of freely chosen authorities transformed the situations they experienced, transforming both the past and the present.

The act of recognition described by Butler [29] reveals the perspective of the role of authorities in relation to research participants and defines the importance and role of recognition in the relevant process of volunteering experience. It was the transformative aspect of the act of recognition, which allowed study participants to become increasingly involved in volunteering, as well as allowed them to experience new situations. Kunkler [24] notes that "people are dependent on and connected with others from the very beginning and always". According to theories of recognition, human self-esteem, self-esteem and coexistence with others are necessary as a condition of a residence permit. While the transformative nature of recognition is not the goal of recognition, it allows recognition to be associated with the transformative nature of the individual, his or her history, and the meaning of life. A strong experience of dependence on a chosen authority allowed study participants to grow by reflecting on an emotionally and existentially strong, sometimes difficult, experience.

In the experience of volunteering, the participants of the research who had partially built or had not built a relationship of trust gained the perspective of a relationship of control with respect to formally intended authorities and themselves. Without building a relationship of trust with authorities, study participants did not experience a relationship of recognition from authorities and experienced isolation from experiences that might shock them internally and lead to experiences of self-esteem, self-worth, or loss. As if free from authority, the participants of the research were faced with an inability to survive the experience, affirming Arendt's [30] freedom without authority - "freedom, having lost the restrictions that protect it, became powerless, unarmed, and doomed" [30]. Freedom in volunteering to express oneself and to survive situations in the process, based on the experiences of the study participants, is a necessary authority that provides an authoritative constraint that the study participants can rely on and trust during the net experience. Surviving a lack of trust and experiencing the impossibility of recognition, participants avoided authentic experiences with beneficiaries and instead of a relationship with others, did not engage in self-experimentation with sleep time, interest in living "for volunteering" and provoking formal authorities and other volunteers. The relationship with oneself has taken on a distinctive meaning, as if emphasizing personal advantage over others and giving up a close relationship based on an indefinite relationship with the Other.

Buber [25] describes the relationship in which I seek control of the Other or objectify the Other as the I-It relationship. I - This occurs in the paradigm of problem thinking when the Next is a problem that needs to be addressed. Atterton et al. (2004), in analyzing 
the relationship between Levinas ethics and the bubbly "I - You" attitude, describe the relationship of control as a lack of ethics toward the Other, when you become an obstacle due to uncontrollability and lack of personal comfort. When you do not trust, you are not in the bubbly relationship I - You, you are detached and controlling in the subject - object relationship I - this. The study identifies the Self as an experience through the description of "superficially happy," which expresses an inner dissociation from volunteering and the fact that volunteering does not become an experienced experience, but an object in which the volunteer does not engage.

By not building a relationship of trust with the authorities and allowing a close relationship with the others receiving assistance, the study participants came to a standstill. Immersion in the situations of the beneficiaries and their life reality has become unbearably difficult for the participants in the study, as if, without finding any other point of recognition and support, the lives of the participants themselves would begin to fall apart: [it seems even hard to comprehend and feel; somehow, it seems now that I remember (Saulè).

The participants of the research self-esteem without a relationship of trust with authority equated with self-esteem of recipients and self-esteem that was insulted and injured, as defined by Honneth [28] when recipients experience humiliation and persistent disrespect. The analysis of the study revealed that the participants in the study, in granting recognition to the beneficiaries, themselves experienced, in a sense, what the individuals they help experienced in terms of the relationship of trust. However, this experience, which increasingly pushed us into helplessness, did not lead study participants to choose authorities and open up a relationship of trust with them. Reflections were in vain due to a lack of trust that did not open the study participants "sincere sharing of inner experiences and personal growth. As the feeling of helplessness intensified, the participants" distrust of formal authorities, which did not become personal authorities, also intensified: [I noticed that social workers, perhaps specifically one social worker, could not work much. [...] That environment, well, I don't know, seems to be an aid environment, [...] but the quality of that aid somehow seems questionable (...) (Saule, 121-125). Although all study participants experienced mistrust of themselves and the Other at the beginning of the volunteering, they went through a control phase, but for some study participants, the experience of the control relationship remained a phase experience and evolved into a relationship of trust. For other participants in the study, distrust of themselves and the Other remained an uninterrupted experience, a kind of aspect of volunteering - superficially happy.

After the participants had established a relationship of trust with the authorities and did not have one with the beneficiaries, the experience of volunteering gave one-sided recognition or self-recognition. Such recognition and a relationship of trust with freely chosen authorities are reminiscent of children's experiences with parents when the volunteer is consistently supported and recognized. The recognition received in volunteering gave self-esteem, self-worth as an unconditionally valuable person. The findings of the study reveal that the experience of unconditional recognition for study participants who did not establish a close relationship with the beneficiaries, but who experienced a relationship of trust with the authorities, seemed to have granted them the status of beneficiaries. The study participants, who did not build a relationship of trust with the authorities, lacked this relationship and, immersed in a one-sided relationship with the beneficiaries, no longer had the internal resources to reflect and understand the volunteering experience. Similarly, only in another perspective the study participants, who did not build a relationship of trust with the beneficiaries, lack this relationship, and those who enjoyed recognition did not immerse themselves in self-reflection in order to accept themselves as weak and imperfect. 
The essential distinguishing feature of volunteering from other activities, in which young adults choose to participate, is the experience of a sense of responsibility and taking responsibility for the activity [31]. The sense of responsibility experienced by the study participants was associated with the relationship of trust they experienced. Those who survived the closest relationship with employees took the most responsibility for the employees, but those who survived the closest relationship with the beneficiaries took responsibility for the following. Schwartz and Howard [32] examining the relationship between responsibility and volunteering, found that responsibility increases rapidly in volunteering and remains very high even after a year. In addition, understanding the consequences of behaviour with volunteering experience is more adequate than not having it. Dutta-Bergman [33] spoke of the strong and complementary coexistence of individualism and community in volunteering, which stems from a unique sense of personal effectiveness and selfishness. This coexistence leads to individual social engagement. Actions that integrate the volunteer lifestyle are combined with intersection points focused on individuality and community. From them arises the definition of a life based on a responsible lifestyle. Although these studies have revealed a strong link between volunteering with responsibility or even responsible lifestyle choices, they do not analyze the process of origin of responsibility in volunteering. The origins of responsibility in the experience of the research participants are related to the concepts of inter-subjectivity and becoming what you are defined by the theory of relativity. Through the interdependence of people, Elias [34] explains the mix of human actions and experiences. "Through the abundance of invisible circuits connected to other people, figuration is created (also translated as design). Many people, who according to their elementary understanding and interdependence, are interconnected in a variety of ways by their respective interweaves of interdependence" [34]. Being so interdependent, people create each other. The interdependence in question is invisible but as real "as the individual" [33]. The experience of participants in the study of surviving a sense of responsibility and taking responsibility for an activity expressed the nature of responsibility through a relationship with the Other, in front of which one becomes responsible for that relationship with the Other.

Theory [24] argues that learning is and can be inter-subjective, relative, and arising from an interpersonal relationship. Such learning bases on Buber's dialogue between, which takes place by moving away from individualism and not into collectivism in the dialogue between two people. The relativity of the study participants in volunteering was experienced dialogically, seeing the person and associating themselves with the person, and thus experiencing a constant interplay as ignorance, uncertainty, but at the same time as devotion and trust. Thus, the relative experience of volunteering also opened the perspective of learning through a relationship to the study participants.

\section{Conclusions}

1. The volunteers' experience of volunteering shows that the relationship of control in trying to fit the lives of met people into a personal imagination - what life should be like - changes through confrontation, surprise and even shock to discover an authentic relationship of trust based no longer on appreciation but on intimacy and communion.

2. Hidden abilities of volunteers, new opportunities and self-disclosure are possible when a close relationship of trust is created.

3. By abandoning preconceptions about the Other and volunteering, the study participants changed the relationship of control to a relationship of trust and on that basis began to volunteer in their environment without waiting for permission, instructions or other actions to legalize volunteering. As the relationship changed, as control shifted to a 
trust-based relationship with those around them, volunteers, realizing the experience, discovered the meaning of volunteering, empowered by trust, and personal freedom and creativity.

4. The relativity of the study participants in volunteering was experienced dialogically, seeing the person and associating themselves with the person, and thus experiencing a constant interplay as ignorance, uncertainty, but at the same time as devotion and trust.

\section{References}

[1] Volunteering Australia, The Intent of the Principles of Volunteering. Suite 2, Level 3, 11 Queens Road, Melbourne, Australia 3004, (2006). W: www.volunteeringaustralia.org

[2] J. Wilson, M. Musick, Law Contemp. Prob. 62(4), 141-168, (2000)

[3] N. Kurapkaitienè, Darbo su savanoriais pagrindai, 184, (Vilnius, 2013)

[4] M.R. Walpe, Happiness of Giving: The Intrinsic Value of Giving and Volunteering on the Quality of Life (Ball State University, 2009)

[5] I. Jonutytè, Savanorystè socialinio ugdymo sistemoje (Klaipėdos universiteto leidykla, 2007)

[6] E. Štuopytė, Savanorių mokymasis vykdant socioedukacinę veiklą nevyriausybinèse organizacijose, Socialiniai mokslai 2, 123-130 (2010)

[7] R.L. Zweigenhaft, J. Armstrong, F. Quintis, A. Riddick, J. Soc. Psychol. 136(1), 25-34, (1996)

[8] Ch. Willard, J. Volunt. Admin. (1997)

[9] F.E. Netting, H.W. Nelson, K. Borders, R. Huber, Admin. Soc. Work 28(3/4), 69-89 (2004). DOI:10.1300/J147v28n03_04

[10] D. Haski-Leventhal, D. Bargal, The volunteer stages and transitions model: Organizational socialization of volunteers, 67-102 (The Tavistock Institute ${ }^{\circledR}$, SAGE Publications, Human Relations, 2008). DOI: 10.1177/0018726707085946

[11] K. McAllum, Management Commun. Quarter. 28(1), 84-110 (2014), DOI:10.1177/0893318913517237

[12] P. Kay, M.J. Polonsky, J. Inglis, J. Nonprofit \& Public Sector Market. 29(1), 64-97, (2017), DOI:10.1080/10495142.2017.1293586

[13] T. Barbour, Alaska Business Monthly 33(10), 126 (2017)

[14] S. Meier, A. Stutzer, Economica 75(297), new series, 39-59 (2008). Retrieved from: http://www.jstor.org/stable/40071730

[15] A. Fee, S.J. Gray, The Int. J. Human Res. Manag. 23, 530-552 (2011)

[16] D. Jezukevičiūtè, J. Skirmantienè, Savanoriškos veiklos metu igytų kompetencijų svarba darbo rinkoje: darbdavių nuomonè, Socialinis Darbas. Patirtis ir Metodai 15(1), 61-83 (2015)

[17] A. Mueler, Antidote to learned helplessness: Empowering youth through service, Reclaiming children and youth, 16-20, (2005). Retrieved from: www . ebsco.com

[18] S. Kerka, ERIC Digest 202, USA, (1998)

[19] M.F. Santinello, Cristini, A. Vieno, L. Scacchi, J. Preven. Interven. Commun. 40(1), 64-79 (2012). DOI:10.1080/10852352.2012.633068

[20] V. Gudžinskienè, N. Kurapkaitienè, Volunteering Expression Using Different Models of Social Work with Third-Countries Citizens. Outlines of Social Innovations in Lithuania (European Scientific Institute, Kocani, Republic of Macedonia, 2013), pp. 158-178

[21] V. Gudžinskienè, N. Kurapkaitienè, Social Work 16(2), 208-225 (2018)

[22] J.A. Smith, P. Flowers, M. Larkin, Interpretative Phenomenological Analisis Theory, Methos and Research (Sage publication, 2009 (reprinted in 2012))

[23] P. Ashworth, K. Greasley, Studies in Higher Education 34(5), 561-576 (2009) 
[24] T. Kunkler, Lernen in Beziehung: zum Verhaeltnis von Subjektivitaet und Relationalitaet in Lernprozessen. feld: transcript Verlag (Paedagogik, 2011)

[25] M. Buber, I and Thou (Martino Publishing, 60196th edition, 2010)

[26] E. Levinas, Alterity and Transcendance (New York, Columbia University Press, 1999)

[27] P. Atterton, M. Calarco, M. Friedman, Buber and Levinas, Dialogue and Difference. (Duquesne Univeristy Press, Pittsburg, Pennsylvania, 2004)

[28] A. Honneth, Recognition and Power (Cambridge University Press, 2007)

[29] J. Butler, Kritik der ethischen Gewalt. Adorno-Vorlesungen erweiterte Ausgabe 2002, Frankfurt/M.: Suhrkamp, (2007)

[30] H. Arendt, Tarp praeities ir ateities (Atviros Lietuvos Knygos, Liedejas: Aidai, 1995)

[31] S.H. Schwartz, J. Personality Soc. Psychol. 30(1), 57-63 (1974)

[32] S.H. Schwartz, J.A. Howard, Social Psychol. Quarterly 43(4), 441-446 (1980)

[33] M.J. Dutta-Bergman, J. Public Relations Res. 16(4), 353-369 (2004). DOI: 10.1207/s1532754xjprr1604_2

[34] N. Elias, Reflections on a Life. Translation (in part) from German by Edmund Jephcott of Über sich selbst; for the biographical interview (first published in Dutch in 1984) the original English manuscript was used (Cambridge: Polity Press) (1994) 